\title{
THE STATE OF WATER AND WASTEWATER MANAGEMENT IN THE MUNICIPALITIES OF THE POLESIE NATIONAL PARK
}

\author{
Krzysztof Jóźwiakowski ${ }^{1}$, Diana Podbrożna ${ }^{2}$, Katarzyna Kopczacka ${ }^{2}$, Michał Marzec ${ }^{1}$, Alina \\ Kowalczyk-Juśko', Patrycja Pochwatka', Agnieszka Listosz ' ${ }^{1}$, Arkadiusz Malik' \\ 1 Department of Environmental Engineering and Geodesy, University of Life Sciences in Lublin, Leszczyńskiego \\ 7, 20-069 Lublin, Poland \\ 2 Student Science Association of Water and Wastewater Management, University of Life Sciences in Lublin \\ Corresponding author's e-mail: krzysztof.jozwiakowski@up.lublin.pl
}

Received: 2017.09.05

Accepted: 2017.10.01

Published: 2017.11.01

\begin{abstract}
The aim of the work is to present the current state of water and wastewater management in the municipalities where the Polesie National Park (PNP) is located. The PNP is situated in Lublin Voivodeship, in the area of six municipalities: Sosnowica, Hańsk, Urszulin, Stary Brus, Wierzbica and Ludwin. The data used in this paper, were obtained on the basis of the surveys conducted in these municipalities in 2016 by the Department of Environmental Engineering and Geodesy of the University of Life Sciences in Lublin. In the analyzed communes, there was a very large disproportion between the usage of sewerage and the water supply network. It has been shown that $79.1 \%$ of the inhabitants living in the afore-mentioned communes used the water supply network and only $22.5 \%$ of them used sewerage. In the discussed communities there are 9 collective, mechanical and biological wastewater treatment plants with a capacity of over $5 \mathrm{~m}^{3} \cdot \mathrm{d}^{-1}$. On the farms located in the scattered areas, which are not connected to the sewerage, wastewater is discharged mainly to the septic tanks. In four out of the six analyzed municipalities, there were 2345 septic tanks registered. Domestic sewage from some farms is purified in household wastewater treatment plants (395 pieces). The plants with the drainage systems are prevalent $(84.9 \%)$, which may contribute to the groundwater quality degradation. In order to protect the natural environment within the communes that form the PNP, it is necessary to undertake the actions that will contribute to the improvement of the current state of water and wastewater management. While solving the existing problems related to water supply and wastewater treatment, it is strongly required to adhere to the principle of sustainable development and use highly effective systems in order to ensure that the ecological effects are appropriate.
\end{abstract}

Keywords: municipality, water supply, sewerage, wastewater treatment plant, septic tank, national park

\section{INTRODUCTION}

Poland has relatively small water resources. The average amount of water per capita in this country is three times lower than in Europe and amounts to approximately $1600 \mathrm{~m}^{3} \cdot \mathrm{M}^{-1}$. This necessitates the rational management of water resources in order to prevent the occurrence of water deficit and there is a strong need to take the action aimed at water protection [Małecki, Gołębiak 2012]. Poland, after join- ing the European Union, has committed itself to respecting the legal regulations concerning the rational management and protection of water. The change of the national law and the need to adapt to the requirements of the Water Framework Directive 2000/60/EC of $23^{\text {rd }}$ October 2000 and Council Directive 91/271/EEC of $21^{\text {st }}$ May 1991 concerning the municipal wastewater treatment prompted the local authorities to take action on the development of water and wastewater infrastructure. 
The proper state of the technical infrastructure, both in cities and in the countryside, is a factor that stimulates the economic development and contributes to the improvement of the quality of the population's life. It is also an essential condition for attaining high environmental standards, which have to be fulfilled by Poland after its accession to the European Union. The basic elements of water and sewage infrastructure include water intake and treatment stations, water and sewerage networks as well as collective and household sewage treatment plants [Kaca 2007]. On the basis of the work of Pawełek [2016] it can be seen that at the beginning of the $21^{\text {st }}$ century, dynamic development of water and sewage systems was observed in Poland and many collective and household wastewater treatment plants were established. However, the needs in this area are still very large.

According to the Polish Central Statistical Office (GUS) data [2016a], in 2015, 84.7\% of the Polish population from the rural areas were connected to the water supply network, while to the sewerage network $-39.2 \%$. These values indicate a very large disproportion between the connection to the water supply and sewerage. However, from other GUS data [2016b] we know that only $39.6 \%$ of the population living in the country use collective sewage treatment plants. The rest of the population discharges sewage mainly to septic tanks and in 2015 there were more than 2 million of tanks registered. Exploitation of these systems is very expensive and if they start leaking, it can contribute to the degradation of surface water and groundwater quality [Jóźwiakowski et al. 2016a; Siwiec 2017]. However, over the past 20 years there has been a systematic decrease in the number of septic tanks observed because there are still more and more household wastewater treatment plants. In 2015, 202783 such objects were registered in Poland [GUS 2016b]. Specific actions, which aim to protect the natural environment, should be undertaken in the protected areas and, above all, in the national parks, which are located within different local government units. It is in such areas that investment in water and sewage management is urgently needed.

The aim of the study is to present the current state of water and sewage management in the municipalities within which the Polesie National Park (PNP) is located. In the paper we used the results of the survey conducted in 2016 by the Department of Environmental Engineering and Geodesy of the University of Life Sciences in
Lublin and data from the Central Statistical Office. Both the statistical data and the results of our own surveys illustrate the situation from 2015. The paper contains the results of the survey carried out in 5 communes, from which a reply was received. Information on the issues examined for Hańsk Commune is limited to the mass statistics. The relatively small share of the PNP area which falls to Hańsk Commune leads to the fact that the absence of the data from the surveys does not significantly affect the results of our research.

\section{THE CHARACTERISTICS OF THE RESEARCH AREA}

The Polesie National Park was created on $1^{\text {st }}$ May 1990 to protect water-peat ecosystems. It is located in Lublin Voivodeship, in the central part of Łęczna Lake District (Figure 1). Currently, the area of the PNP is about $97 \mathrm{~km}^{2}$. Forests account for about $43 \%$ of the total area, and $25 \%$ are wastelands with peat-bogs and bog-moors of high natural value. The remaining areas of the PNP include arable lands and waters [Michalczyk et al. 2012].

The Polesie National Park protects a territory that is very unique in Europe, known as a tundra or a forest-tundra, located in the furthest south-west of Europe. There are 140 northern species of plants found in the Park. In addition, the presence of many plant species of the Atlantic region (25) and southern region (30) creates a unique flora peculiarity. The nature of the PNP is extremely rich and includes, above all, watermarsh areas, especially natural fragments of low, transition and high peat bogs, with their characteristic species diversity. Insectivorous plants, orchids and many species that are post-glacial relics are found here. The park is also home to moose, European pond turtle, beaver and otter [http://www.poleskipn.pl].

In the PNP, 208 plant associations have been distinguished, 30 of which represent forest and scrub communities, and the other 178 are nonforest. The flora of PNP is represented by about 260 species of algae, 130 species of bryophytes and about 1000 species of vascular plants (107 of which are rare species). 120 species are representatives of the Central European flora. Nearly 140 species are plants of the northern zone, and the amount of the Atlantic relics is about 25 species. In the Park, there are also plants specific for steppe (Pontic) and mountain regions [http://www.poleskipn.pl]. 
According to the hydrogeological division of Poland, the PNP is located in the Central Vistula region. The area of active water exchange within the chalk formations is up to $100-120 \mathrm{~m}$ below the ground level and the ceiling of the bottom chalk formations occurs at a depth of 400-850 m. Depending on the geological nature of the PNP area, the groundwater level remains within a wide range of $1 \mathrm{~m}$, even for long-lasting periods of drought to $5 \mathrm{~m}$, and in occasional cases to $10 \mathrm{~m}$. The surface water network of the Polesie National Park consists of the following rivers: Piwonia Górna, Piwonia Dolna, Włodawa, Mietiuk, Bobryk, field drains, supplys and lakes: Łukie, Karaśne, Moszne, Długie as well as ponds and wetlands. Within the protective zones of the Park, the following lakes can be found: Zagłębocze, Gumienko, Cycowe, Zienkowskie, Płotycze, Karaśne (near Urszulin), Wereszczyńskie and Wytyczno [http:// www.poleskipn.pl].

The national parks, although protected by law, are located within different local government units. That is why the anthropogenic activity can adversely affect not only the state of the natural environment but also the protection of the flora and fauna in the park. The Polesie National Park is located in six communes: Sosnowica, Urszulin, Wierzbica, Stary Brus, Hańsk and Ludwin (Figure 1, Table 1).

More than $52 \%$ of the Polesie National Park's area is within Urszulin Commune and almost $25 \%$ in Sosnowica Commune (Table 1). Less than $23 \%$ of the PNP's area is located in the other 4 municipalities: Wierzbica, Stary Brus, Hańsk, and Ludwin. The human activity in these communes may either have a positive or a negative impact on the state of the natural environment in the PNP. In order to preserve the natural and landscape values of the PNP, it is extremely important to determine the state of water and wastewater infrastructure in the area of the discussed communes and to indicate the actions that will contribute to the protection of the environment from degradation.

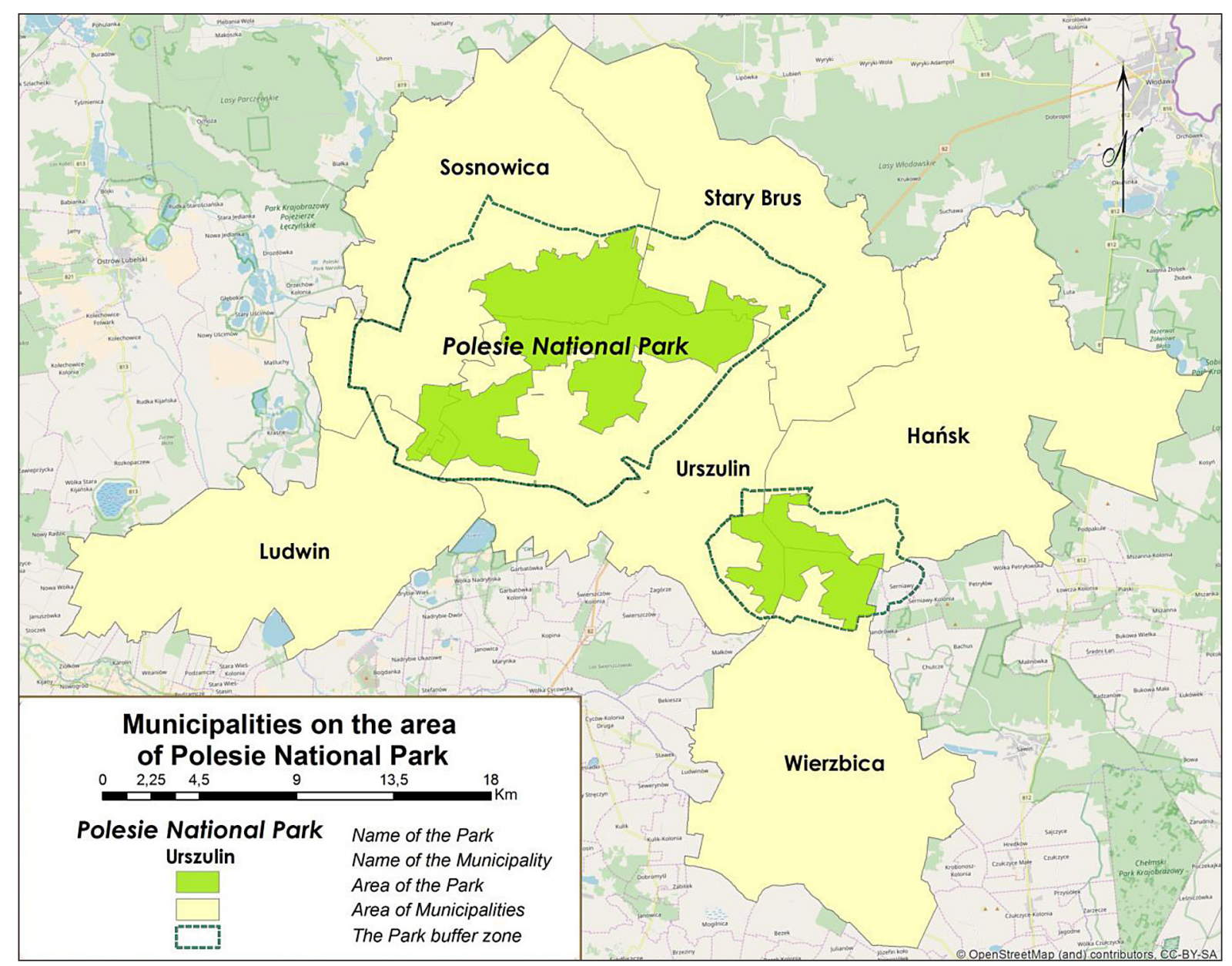

Fig. 1. The location of the PNP within the area of the analyzed communes 
Table 1. The characteristics of the communes within which the Polesie National Park is located

\begin{tabular}{|c|c|c|c|c|}
\hline $\begin{array}{c}\text { Name of the } \\
\text { commune }\end{array}$ & $\begin{array}{c}\text { The area of the } \\
\text { commune }\left[\mathrm{km}^{2}\right]\end{array}$ & $\begin{array}{c}\text { The area of the park within the } \\
\text { commune }\left[\mathrm{km}^{2}\right] / \% \text { of the PNP area }\end{array}$ & $\begin{array}{c}\text { The amount of the } \\
\text { inhabitants of the } \\
\text { commune }\end{array}$ & $\begin{array}{c}\text { Population density } \\
{\left[\text { people/ } / \mathrm{km}^{2}\right]}\end{array}$ \\
\hline Sosnowica & 172.3 & $23.92 / 24.73$ & 2657 & 16 \\
\hline Urszulin & 172.1 & $50.82 / 52.40$ & 4275 & 24 \\
\hline Wierzbica & 145.8 & $9.29 / 9.57$ & 5291 & 36 \\
\hline Stary Brus & 131.7 & $4.88 / 5.03$ & 2186 & 16 \\
\hline Hańsk & 176.3 & $5.90 / 6.08$ & 3784 & 22 \\
\hline Ludwin & 122.0 & $2.18 / 2.24$ & 5433 & 45 \\
\hline
\end{tabular}

\section{RESULTS OF THE RESEARCH AND DISCUSSION}

The water supply network is one of the most important and, at the same time, the most expensive ways of supplying people with water. Its primary task is to provide continuous delivery of water to all the customers, under the required pressure and in the amount that meets their needs. Figure 2 shows the length of the water supply network in the 5 communes within which the Polesie National Park is located.

The longest water supply network is located in Ludwin Commune - $138.5 \mathrm{~km}$, which provides water supply for $75.2 \%$ of the population of this municipality. On the other hand, in Wierzbica Commune, the water supply system with the length of $130.94 \mathrm{~km}$ is used by $79.4 \%$ of inhabitants while in Urszulin Commune, the $117 \mathrm{~km}$-long network provides water for $89.3 \%$ of the residents. The smallest percentage of the inhabitants $(60.2 \%)$ use the water supply system in Sosnowica Commune, where the network's length is $77.8 \mathrm{~km}$. The shortest water supply network is located in Stary Brus Commune - 62.7 $\mathrm{km}$; however, it supplies water to $91.5 \%$ of this district's inhabitants. On the basis of the survey results it can be stated that in $2015,79.1 \%$ of the population in the analyzed communes used water from the water supply network. This is a lower value than the one which was found in 2011 in 70 districts located in Lublin Voivodeship (84.8\%) [Jóźwiakowski et al. 2012] and also than that which was reported by GUS [2016a] for rural areas in Poland in 2015 (84.7\%). The presented data indicate that in the communes within the PNP area, it is necessary to further expand the water supply network in order to supply more than $20 \%$ of the population with water.

Sewerage network. The construction of water supply systems should always be accompanied by the development of sewerage networks and wastewater treatment plants, so as to reduce the pollution of the surface water and groundwater. Owing to the fact that Lublin Voivodeship is not very rich in surface water, it is important to take particular care of groundwater. In 2015, it was collected in the amount of $91.1 \mathrm{hm}^{3}$, which constituted $100 \%$ of water delivered to the population [Statistical Office in Lublin 2016].

The choice of the sewage system should always be preceded by a concept that will consider not only the technological and technical aspects, but also the economic ones, including the capital

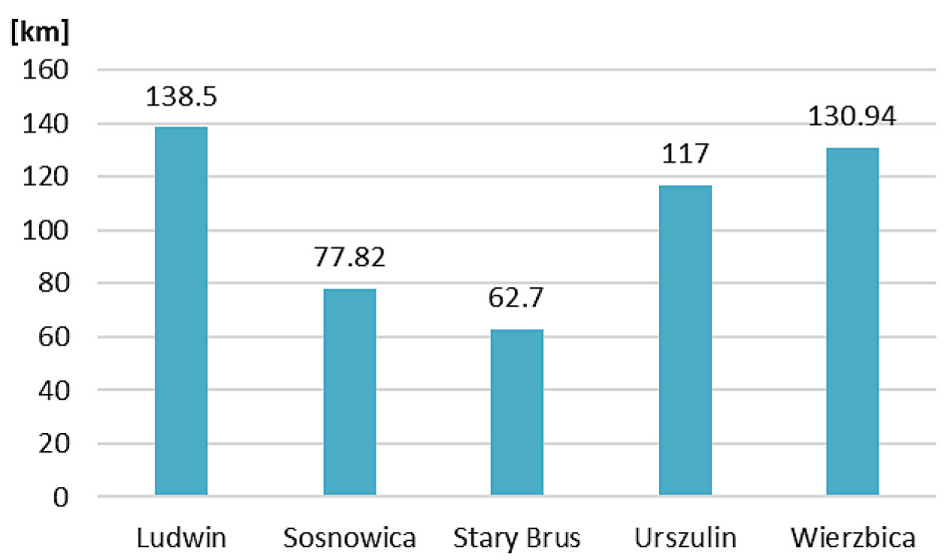

Fig. 2. Lengths of the water supply networks in the communes within which the PNP is located 
expenditure and exploitation costs. It is also important to take the local conditions into account, mainly the land-water conditions or the possibility to use a receiver of the treated wastewater [Heidrich, Stańko 2008].

Unfortunately, the extent of the sewerage in the Polesie National Park is much lower than in the case of water supply network (Figure 3). The longest sewage network is found in Urszulin Commune $-52.4 \mathrm{~km}$, which provides sewage disposal from $23.2 \%$ of the inhabitants of this municipality. In Ludwin Commune, the length of the sewerage is $31.2 \mathrm{~km}$, and it serves only $8.2 \%$ of the population. Much shorter sewage networks are owned by the communes of Sosnowica and Wierzbica -15 and $14.2 \mathrm{~km}$, respectively, while the percentage of residents they serve is 28.4 and $29.6 \%$, respectively. The shortest sewerage network exists in Stary Brus Commune $-4.1 \mathrm{~km}$, it provides sewage collection from $24.3 \%$ of the inhabitants. On the basis of the results of the surveys, it can be stated that on average $22.5 \%$ of the population in the analyzed communes used the collective sewerage system in 2015. This is a value slightly higher than that which was found in 2011 in 70 municipalities of Lublin Voivodeship (18.6\%) [Jóźwiakowski et al. 2012], but much lower than the one which was reported by GUS [2016a] for the rural areas in Poland $(39.2 \%)$ in 2015.

The presented data show a high disproportion in how the inhabitants of the analyzed communes are provided with water and sewage supply network. The worst situation has been found in Ludwin Commune, where $75.2 \%$ of the population use the water system, while the sewage system was used by only $8.2 \%$ of people. High costs of building a sanitary infrastructure, which re- sult from the sparse settlement in the rural areas, make the development of the sewage network very weak. In the urban areas, where the concentrated settlement is dominant, the compact sewage system is being built at a faster rate [Pawełek 2016]. According to the data obtained during the survey, there is a strong need to further expand the sewage network in the communes within which the PNP is located and this will enable the disposal of sewage to collective sewage treatment plants from over $77 \%$ of the population. Another solution may be the construction of some local wastewater treatment systems, i.e. household wastewater treatment plants.

The collective wastewater treatment plants are built in the rural areas where the concentrated development exists. The collective treatment plants should be adjusted to the amount of the wastewater which is carried in order to perform treatment of sewage with optimum hydraulic and contamination load, ensuring efficient elimination of its negative environmental impact. In the rural areas, this is difficult to carry out because of the limited financial means and, therefore, the local governments are in a dilemma whether to build a sewage network or a wastewater treatment plant first. The construction of the network itself may result in a cumulative stream of sewage, which, given the lack of the treatment plant, will cause a significant environmental damage. On the other hand, the construction of a wastewater treatment plant at the very beginning involves, for a period of several months or years, mostly purification of very concentrated sewage which disrupts the normal course of the pollutant removal processes [Siwiec 2017].

In the communes, where the Polesie National Park is located, there are 9 collective sewage

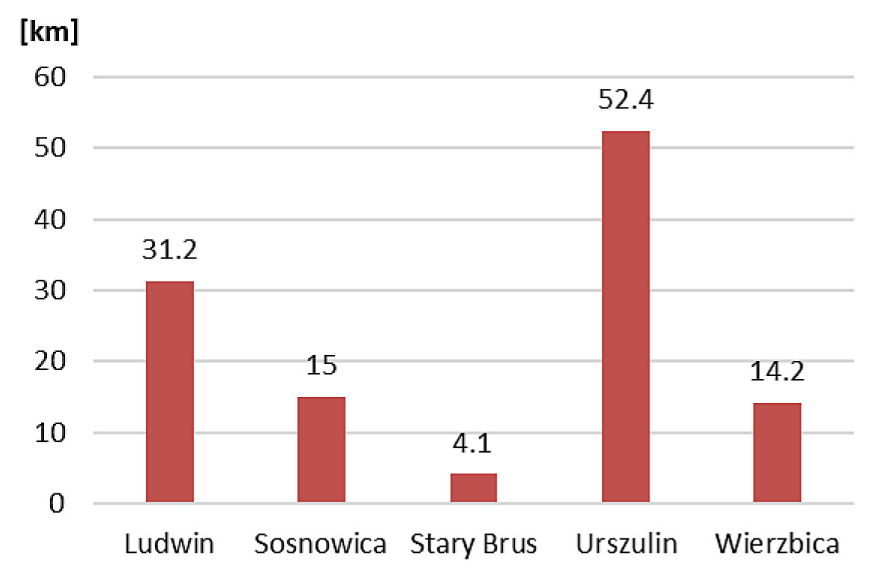

Fig. 3. The lengths of the sewerage networks in the communes within which the PNP is located 
treatment plants with a capacity that is greater than $5 \mathrm{~m}^{3} \cdot \mathrm{d}^{-1}$. These are mainly biological treatment plants. The majority, i.e. 3 of the objects are located in Sosnowica Commune. In addition, Wierzbica and Ludwin have 2 such objects each, whereas Stary Brus and Urszulin have 1 plant each (Table 2).

The communes within the Polesie National Park are located in the rural areas, where the sparse housing development is not conducive to the construction of the sewage networks and collective wastewater treatment plants. Therefore, the main method of sewage management is to collect it in the septic tanks or to drain it to the household wastewater treatment plants.

Septic tanks are used for a periodic collection of wastewater, from where they are then exported by sewage cars to a given sewage disposal station located near the collective wastewater treatment plants. Septic tanks are characterized by low investment costs but they are expensive during exploitation due to the high costs of draining and sewage disposal. However, the septic tanks are often leaky and thus they pose a potential threat to the quality of the groundwater that is most often used as a source of drinking water supply [Heidrich 1986].

In 2015, 2345 septic tanks were registered in four out of the six analyzed communes. The highest number of tanks was found in Wierzbica Commune -842 pieces and Urszulin Commune - 612 pieces, while in the communes of Sosnowica and Ludwin - 525 and 366 pieces, respec-

Table 2. The collective wastewater treatment plants with a capacity of more than $5 \mathrm{~m}^{3} \cdot \mathrm{d}^{-1}$ in the communes where the PNP is located

\begin{tabular}{|c|l|c|}
\hline L.p. & \multicolumn{1}{|c|}{$\begin{array}{c}\text { The name of the sewage } \\
\text { treatment } \\
\text { plant/ the commune }\end{array}$} & $\begin{array}{c}\text { The capacity of } \\
\text { the } \\
\text { treatment plant } \\
{\left[\mathrm{m}^{3} / \mathrm{d}\right]}\end{array}$ \\
\hline 1 & Ludwin (Ludwin Commune) & 300 \\
\hline 2 & Kaniwola (Ludwin Commune) & 150 \\
\hline 3 & $\begin{array}{l}\text { Sosnowica (Sosnowica } \\
\text { Commune) }\end{array}$ & 120 \\
\hline 4 & Zienki (Sosnowica Commune) & 60 \\
\hline 5 & Turno (Sosnowica Commune) & 30 \\
\hline 6 & $\begin{array}{l}\text { Stary Brus (Stary Brus } \\
\text { Commune) }\end{array}$ & 75 \\
\hline 7 & Urszulin (Urszulin Commune) & 287 \\
\hline 8 & $\begin{array}{l}\text { Busówno-Kolonia (Wierzbica } \\
\text { Commune) }\end{array}$ & 300 \\
\hline 9 & $\begin{array}{l}\text { Wólka Tarnowska (Wierzbica } \\
\text { Commune) }\end{array}$ & 50 \\
\hline
\end{tabular}

tively. The obtained information shows that every third household located in the investigated area uses such a solution of wastewater management, which poses a serious threat to the quality of the groundwater.

According to the GUS data [2016a], in recent years, the amount of the septic tanks in Poland has been declining, mainly due to their high exploitation costs. In 2014, there were 2.192 million of such tanks, while in 2015 their number was 2.136 million. On the other hand, there has been a significant increase in the number of the household wastewater treatment plants observed in 2014 there were 181 thousand of such units but in 2015 - already 203 thousand [GUS 2016a].

Household wastewater treatment plants began to be built in the mid-1990s and recently they have become one of the most essential elements of the sanitary infrastructure in the rural areas in Poland. According to the Polish Standard PN-EN 12566, household wastewater treatment plants are objects that serve up to 50 inhabitants. Nowadays, in our country the most often built types of the household wastewater treatment plants are these with an active sludge or a biological bed as well as with a drainage system and the constructed wetland systems [Krzanowski, Wałęga 2007]. The first element of the household sewage treatment plant should be a preliminary sedimentation tank, which removes the largest pollutants [Pawęska et al. 2011]. Its absence or an improper operation may cause malfunction of the whole sewage treatment system.

According to the received data, there are 395 household wastewater treatment plants in the 5 surveyed communes, including 335 units with a drainage system, 57 units with an active bed and 3 constructed wetland systems. The majority of such objects are located in Stary Brus Commune178 , while the least number of the plants is found in Ludwin Commune - 27 objects (Figure 4).

The objects with a drainage system are most often used in the household wastewater treatment plants in Poland [Jóźwiakowski 2012]. Surveys have shown that their number reaches $85 \%$ of all the household wastewater treatment plants in the analyzed communes (Figure 5). Jóźwiakowski et al. [2014] found that the plants with a drainage system are very dangerous for the groundwater quality because they do not provide effective removal of the pollutants, mainly biogenic com- 


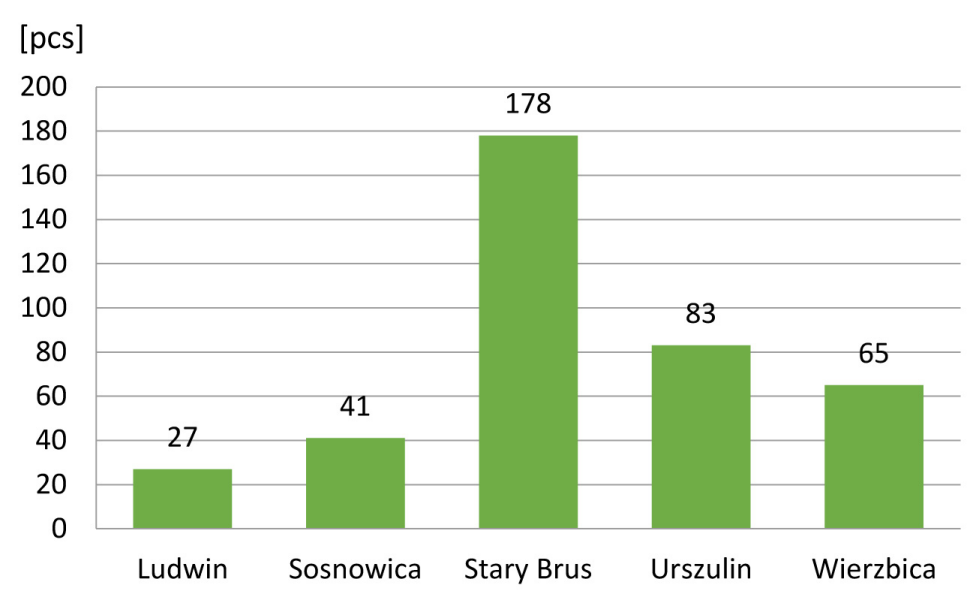

Fig. 4. The amount of the household wastewater treatment plants in the municipalities within which the PNP is located

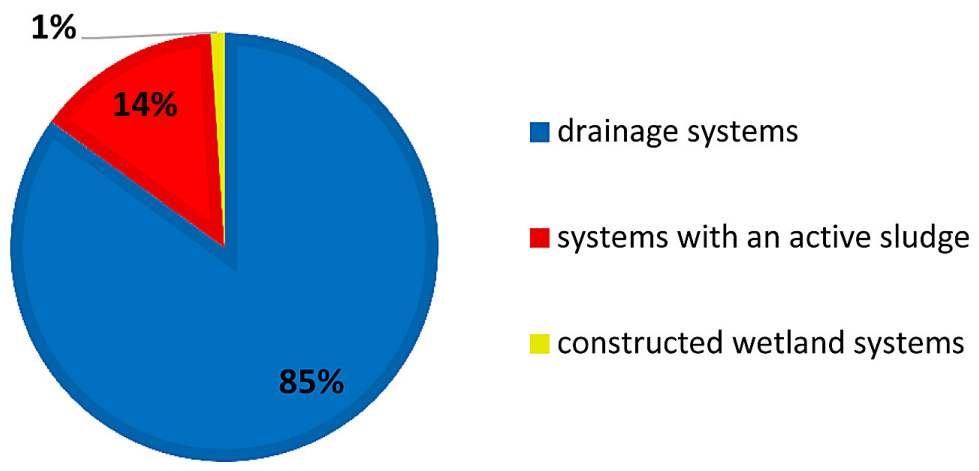

Fig. 5. The types of the household sewage treatment plants (in \%) in the communes within the Polesie National Park

pounds (nitrogen and phosphorus). Therefore, in the coming years in Poland, it would be appropriate to prohibit or restrict the usage of these systems, as they dispose the wastewater treated only mechanically to the ground [Jóźwiakowski 2012]. In the recent years, the interest in the constructed wetland systems in our country has increased. These are wastewater treatment systems where the level of the wastewater can be maintained below or above the surface of the ground, which is favorable to the development of hydrophytes. These treatment plants are environmentally safe, they easily integrate into the surrounding landscape and provide great efficiency of sewage treatment. For several years they have been successfully used in many communes in Lublin Voivodeship as well as in the Roztocze and Polesie National Park, where 4 such objects have been built so far. Some of them, apart from their high functionality, are characterized by atypical shapes such as resembling a fir or a turtle [Jóźwiakowski et al. 2016b].

\section{CONCLUSIONS}

1. The present state of the water and sewage management in the communes within which the Polesie National Park is located is not satisfactory and may contribute to the natural environment pollution.

2. In the analyzed municipalities, there was a very large disproportion between the usage of the sewerage and the water supply network. It was shown that about $79.1 \%$ of the population from the investigated areas used the water supply network and $22.5 \%$ used the sewage system.

3 . In the discussed communes, there are 9 collective, mechanical and biological wastewater treatment plants with a capacity of over $5 \mathrm{~m}^{3} \cdot \mathrm{d}^{-1}$. On the farms located in the areas with the sparse housing development that are not connected to the sewerage system, wastewater is discharged mainly to the septic tanks. In 2015, there were 2345 septic tanks registered in four out of the six analyzed communes. 
4. Domestic sewage from farms is cleaned in the household wastewater treatment plants (395 pieces), among which the ones with a drainage system are prevalent $(84.9 \%)$, possibly contributing to the degradation of the groundwater quality. The development of the home wastewater treatment plants network should be based on the highly effective solutions, including treatment plants with an active sludge, a biological bed or constructed wetland systems.

5. In order to protect the natural environment of the Polesie National Park, it is necessary to undertake the actions that will contribute to the improvement of the current state of water and sewage management. While solving the existing problems related to the water supply and wastewater treatment, it is required to apply not only the principle of the sustainable development but also high-effective systems which ensure appropriate ecological effects.

\section{REFERENCES}

1. Dyrektywa Rady $91 / 271 / \mathrm{EWG}$ z dnia 21 maja 1991 r. w sprawie oczyszczania ścieków miejskich.

2. GUS 2016a. Infrastruktura komunalna w 2015 roku. Główny Urząd Statystyczny, Warszawa.

3. GUS 2016b. Ochrona środowiska. Główny Urząd Statystyczny, Warszawa.

4. Heidrich Z. 1986. Charakterystyka technicznoekonomiczna układów kanalizacyjnych na terenach zabudowy jednorodzinnej. Ochrona Środowiska 448/1-2, 27-28.

5. Heidrich Z., Stańko G. 2008. Kierunki rozwiązań oczyszczalni ścieków dla wiejskich jednostek osadniczych. W: Infrastruktura i Ekologia Terenów Wiejskich Nr 5, PAN Oddział w Krakowie, Komisja Technicznej Infrastruktury Wsi, 169-177.

6. Jóźwiakowski K. 2012. Badania skuteczności oczyszczania ścieków w wybranych systemach gruntowo-roślinnych. Monografia. Rozprawa habilitacyjna. Infrastruktura i Ekologia Terenów Wiejskich. PAN Oddział w Krakowie. Komisja Technicznej Infrastruktury Wsi, 1/2012, 232.

7. Jóźwiakowski K., Pytka A. Marzec M., Gzińska M., Dąbek J. Głaz B. Sławińska A. 2012. Rozwój infrastruktury wodno-ściekowej w województwie lubelskim w latach 2000-2011. Infrastruktura i Ekologia Terenów Wiejskich. PAN Oddział w Krakowie. Komisja Technicznej Infrastruktury Wsi, 3/I/2012, 73-86.

8. Jóźwiakowski K., Steszuk A., Pieńko A., Marzec M., Pytka A., Gizińska M., Sosnowska B., Ozonek J. 2014. Ocena wpływu przydomowych oczysz- czalni ścieków $\mathrm{z}$ drenażem rozsączającym na jakość wód podziemnych w studniach kopanych i głębinowych. Inżynieria Ekologiczna, 39, 74-84.

9. Jóźwiakowski K., Listosz A., Gizińska-Górna M., Pytka A., Marzec M., Sosnowska B., KowalczykJuśko A., Grzywna A., Mazur A., Obroślak R. 2016a. Effect of anthropogenic pollutants on the quality of surface waters and groundwaters in the catchment basin of lake Bialskie. Journal of Ecological Engineering, 17(4), 154-162.

10. Jóźwiakowski K., Gajewska M., Marzec M., Gizińska-Górna M., Pytka A., Kowalczyk-Juśko A., Sosnowska B., Baran S., Malik A., Kufel R. 2016b. Hybrid constructed wetlands for the National Parks - a case study, requirements, dimensioning, preliminary results. In: Vymazal J. (Ed.) Natural and Constructed Wetlands. Nutrients, heavy metals and energy cycling, and flow. Springer International Publishing Switzerland, 247-265.

11. Kaca E. 2007. Infrastruktura wodno-ściekowa na wsi na przełomie wieków. Problemy Inżynierii Rolniczej, 15, No. 1, part 2, 35-46.

12. Krzanowski S., Wałęga A. 2007. New technologies of small domestic sewage volume treatment applied in Poland. Infrastruktura i Ekologia Terenów Wiejskich, 3, 69-78.

13. Małecki Z.J., Gołębiak P. 2012. Zasoby wodne Polski i świata. Zeszyty Naukowe. Inżynieria Lądowa i Wodna w Kształtowaniu Środowiska, 7, 50-56.

14. Michalczyk Z., Mięsiak-Wójcik K., Turczyński M. 2012. Poleski Park Narodowy. W: Bogdanowicz R., Jokiel P., Pociask-Karteczka J. (red.) Wody w parkach narodowych Polski. Instytut Geografii i Gospodarki Przestrzennej Uniwersytetu Jagiellońskiego, Komisja Hydrologiczna Polskiego Towarzystwa Geograficznego, Kraków.

15. Pawełek J. 2016. Degree of development and functionality of the water supply and sewage systems in rural Poland. Barometr Regionalny, 14(1), 141-149.

16. Pawęska K., Pulikowski K., Strzelczyk M., Rajmund A. 2011. Osadnik gnilny - podstawowy element przydomowej oczyszczalni ścieków. Infrastruktura i Ekologia Terenów Wiejskich, 10, 43-53.

17. Ramowa Dyrektywa Wodna 2000/60/WE z dnia 23 października 2000 roku.

18. Siwiec T. 2017. Stan obecny zaopatrzenia w wodę, odprowadzania ścieków oraz problemy rozwoju gospodarki wodno-ściekowej na terenach wiejskich. W: Jóźwiakowski K., Siuda W. (red.) Ochrona i kształtowanie zasobów wodnych na terenach wiejskich. Fundacja na rzecz Rozwoju Polskiego Rolnictwa, Warszawa, 29-33.

19. Statistical Office in Lublin 2016. http://lublin.stat. gov.pl 